\title{
International Migration of Highly Qualified Housewife Mothers and Their Career Concerns
}

\author{
Arzu Kurcal Sahin 1 , Dr. Serpil Aytac ${ }^{2}$ \\ ${ }^{1}$ Institute of Social Sciences, Bursa Uludag University, Bursa, Turkey \\ ${ }^{2}$ Department of Labour Economics and Industrial Relation, Bursa Uludag University, Bursa, Turkey \\ *Correspondence: Dr. Serpil Aytac, Email: saytac@uludag.edu.tr
}

\begin{abstract}
The purpose of this study was to explore the experiences of highly educated mothers with at least one child who have left their jobs and have immigrated to the UK because of their spouse's job. The study investigates the barriers that these Turkish women may face in the UK. Research on immigrants has been mostly restricted to quantitative methods which rely on statistical data sets. A search of the literature revealed that qualitative studies are rarely used within the field. In order to examine this issue, in-depth interviews were held with 20 Turkish participants who meet the research criteria. Integrating these findings with relevant international migration theories, this study reveals that those highly educated Turkish women with advanced career success who took part in this research have not managed to break the cycle of traditional gender roles. It also shows that these women have not only taken care of their children, but also have established a harmonious family environment in order to assist their husbands' career. The findings of this study show that moving to the UK with their spouses inevitably has resulted in a decline in the career success, financial and social status for the participants.
\end{abstract}

Keywords: Highly qualified, Housewife mothers, International immigration, UK

\section{ARTICLE INFORMATION}

Author(s): Arzu Kircal Sahin, Dr. Serpil Aytac

Received: 15 Feb, 2021; Accepted: 20 Feb, 2021; Published: 25 Feb, 2021 ; e-ISSN: 2347-4696;

Paper Id: BMN-IJBMR-2021-17;

Citation: doi.org/10.37391/IJBMR.090107

Webpage-link:

https://ijbmr.forexjournal.co.in/archive/volume-9/ijbmr-090107.html

\section{INTRODUCTION}

The individuals, having a job as independent from the industry, are affected from change of place in close or far ranges either in the country, or among other countries. One of the effects of global economy on personal lives is the mobility of labor. The employees are willing to join other communities around the world along with their families. In this way, they may find new jobs, and they may maintain their present jobs, or may show progress in their jobs [1].

In the era of globalization, gradually more people are moving around the globe and migrating to other countries because the world is more connected than ever as a result of advanced telecommunications, easier transportation opportunities and unprecedented extension of goods and capital markets. Castles and Miller have defined this phenomenon as "era of immigration" [2]. Most of the people are mainly trying to move to countries that are more developed than their own countries.

For instance, UK has been a significant target country for the immigrants by various reasons, and an extra increase in the number of immigrants had been observed in the last fifty years, and this has further increased especially in the last 15 years. The country faced immigration flow from Europeans who were using their rights to move freely. In December 2019, about 715,000 individuals had immigrated to the UK, whereas about 403,000 individuals had immigrated from the UK [3]

\section{CAREER PROBLEM OF WOMEN, AND IMMIGRATION}

The preference of staying at home requires self-sacrifice at many levels. DeSimone defines the highly qualified housewife mothers as ones bearing the sense of guilt by focusing only on their families instead of combining career and family commitments. According to DeSimone, the women also face conflict of roles between being a baby-sitter and professional success [4].

Not only in Turkey but also in other parts of the world, the dominant culture associates motherhood with child care, and fatherhood with earning a living for the family [5-8].

When the Industrial Revolution had stepped in, paid workers, and generally husbands had taken their place in the family as the main economic unit. The house had become the shelter of cold and competitive public domain, and for that reason, the women had been associated with the house, and with everything it represents [9-11]. The women and men had not just been physically dissociated in these different domains, but the women had also been ideologically excluded from public domain, and they had been defined with their familial roles in private space. The free labor of women had been trivialized despite being deemed very important for the development of children [12]. As a result of industrialization of the society, traditional values, such as deeming the husband as the one earning a living for the family, and the wife as the one taking care of the house, had settled in the ideal of the society.

Throughout the history, the opportunity of having higher education was not available for women. They had been confined in the roles of spouse, mother, and housewife in the family life. However, throughout 19th century and by the 
beginning of 20th century, great progress had been made in the participation of women in business life along with the increase of educational level of women [13]. Thus, along with the participation of women in higher education, the doors of professions, where men had been dominant previously, have been opened also for women. But for women who used to stay in houses for centuries, participation in business life has led to conflicts with respect to their preferences between career and family [14].

Theoretically, it has been understood that women's psychology is subject to conflict between "me" and "us", and between personal success and nurturing the improvement of others [15]. The struggle between giving to others and making for one's own self is inherent in women, and potentially it may cause personal development as well as inner conflicts. It has also been found out that social pressure is shaping the motherhood experience, and the personal expectations with respect to preferences regarding motherhood and business. Studies on the subject [16-18] indicate that conflict of roles and guilt are part of the psychological states of both unemployed and employed mothers.

A woman's choice between taking the continuously increasing opportunities in education and career, and being a mother at home is complex. There are a few studies carried out in order to understand the experiences of highly qualified housewife mothers. And these studies are mostly quantitative [4, 19-21]. For this reason, a qualitative design was used in the study in order to access participants' perceptions, meanings and experiences of migration and its effects on their career. The themes arising from this study will be beneficial in terms of fathoming the essence of the complexity of highly qualified immigrant women's experiences.

According to Faludi, the inner conflicts of women between their motherhood roles and professional roles are deeply affected by the external social powers. Faludi expresses that our society consists of "super mother" images. "Super mother" namely the mother who can be everything for everyone, the perfect mother, spouse and worker. What is the experience of women who reject the ideal of "super mother", and instead who prefer to focus all their energy on growing their children? [22]

The experiences of mothers, who prefer career, continue to draw great interest in social science studies. Most of these studies address the role of mother around employment and various psychological effects, sense of guilt [4, 17], and conflict of roles $[23,24]$. Other studies focus on differences between working mothers and mothers staying at home [23] [25-27]. While there are some studies regarding highly qualified housewife mothers [4, 19], it is important to gain deeper insights into the experiences of these women.

For this reason, understanding the experiences of women, who had spent time, energy and money for having license and even master's degree, and who decide to stay at home along with their children following immigration, is important in terms of women's use of their real potentials.

\section{RESEARCH'S PURPOSE AND METHOD}

In this study, the aim was to understand the experiences of highly qualified immigrant housewife mothers who live in the UK. While many studies focus on employed mothers, who deal with both career and motherhood, there is a lack research on highly qualified mothers who choose to stay at home with their children. And when immigration is also involved in, the case is becoming much different. In this study, answers for the following questions were sought while researching the experiences of highly qualified immigrant mothers: (a) What are the main reasons of mother's preference for staying at home? (b) What is the impact of immigration on their career? (c) How does being economically dependent on the spouse affect the lives of these mothers? How does staying at home together with their child/children following immigration affect these mothers while they had been actively working prior to immigration? What are their positive experiences following their decision of staying at home? Qualitative research method was used in order to answer answers these questions, and to understand and interpret the social and economic positions of women. The study utilized in-depth interviews conducted online due to COVID-19 pandemic. Highly educated Turkish mothers with at least one child who have left their jobs and have immigrated to the UK because of their spouse's jobs participated in this study. In recruiting the participants, social media (Twitter, Facebook, LinkedIn etc.) was used. 20 individuals in total, who were deemed to meet the criteria agreed to take part in the study. Rapport was built via WhatsApp conversations and phone calls and online Zoom invitations were sent for interviews at a time and date that suit the participants the best. The interviews were conducted between October 28, 2020 to December 03, 2020. Each participant is assigned a pseudonym in order to preserve the privacy of the participants.

Semi-structured interview questions were formulated by the help of theoretical background information obtained from literature. Data collection means were approved by the university's ethical committee (of October 23, 2020 with no: 2020-08/5). Each interview lasted from 35 minutes to 1 hour 30 minutes. Thematic analysis was used in order to examine the qualitative interview data. The analysis involved data categorization and coding which then led to the development of categories this paper uses for reporting the findings.

\subsection{Participants' Demographic Characteristics}

The participants included 20 highly educated Turkish housewife mothers who had immigrated to the UK due to career commitments of their spouses. The interviewers were at the age range of 30-53, and they were mostly in the midst of their 40s. They were living in the UK along with their spouses and children. They had immigrated to the UK as being dependent on their husbands. 8 of them had master's degree, one of them had doctoral degree, and the remaining 11 of them had degrees from various universities, and they had professional careers prior to moving to the UK. 16 of the participants had made a decision for immigration -to the UK- 
for the first time, and the other 4 individuals had settled in the UK after living in different countries. The jobs of their spouses, and economic, social and political reasons had been asserted by them as the bases of their decisions for immigration. When their occupational groups were considered, it was understood that 5 of them were teachers, 3 of them were engineers, 3 of them were bankers, 3 of them were managers at private companies, 2 of them were academics, one of them was a medical doctor, one of them was a dentist, one of them was an architect, and one of them was a public officer. Thus, all of them are highly qualified individuals, who obtained good positions in their careers in Turkey (one in Germany), and who have significant human and social capital.

Number of children each participant varies between one and three, and the youngest of their children was 3 months old, and the oldest one was of age 23. Annual income of the family varied between $£ 25,000$ and $£ 100,000$, and the annual income of half of the participants was between $£ 25,000-£ 50,000$. A participant didn't share her family's annual income due to rules of the company where her spouse was working.

Majority of the participants (12 individuals) were residing in London along with their families. 4 of them were living in the UK for 0-1 years, 5 of them for 1-2 years, 7 of them for 3-4 years, and 4 of them for more than 5 years.

\section{FINDINGS}

In analyzing the data, the focus was on identifying the most common themes that would help the researcher gain better insights into the experiences of the participants. These included: motive for immigration; challenges as experienced by the participants in the UK and reasons behind mothers' preference for sating at home.

\section{Motive for immigration}

The business of their spouses, the future, and especially the education of their children had been among the main reasons behind why these participants chose to immigrate to the UK. Fatma, one of the participants, was among the ones who preferred to immigrate for the future of her children, and she, for instance, said:

"I always used to feel a bit different than the normal people. I was feeling like I didn't belong to my country much. And as I always had the problem of foreign language in my life, my dream was ensuring my children to have education in a foreign country. In this direction, we decided to come here." (Fatma)

Ezgi, on the other hand, was one of those who actually never wanted to immigrate. But she made it to England due to her spouse. She communicated her feelings as follows:

"I'm not a woman who likes to live away from her family, away from her mother and father and loved ones. I visited other countries a lot, but it was just for touristic intentions. I never intended and wished to settle." (Ezgi)
And Sevda communicated her feelings for the process of immigration as follows:

"Literally, I didn't speak to him (my spouse) for a week, and I cried for a week. I could never accept to go outside of Istanbul. I didn't accept it, but I also didn't want to wait for my spouse. Because I didn't want the people to tell me later on that I couldn't have a better life due to my hesitation. And I also didn't want to leave my spouse alone. Because he was thinking that we would have a better future in here after living abroad for a while. I faced a very hard transition period. (...) Then I said okay, let's head on." (Sevda)

And Betül, who had to immigrate due to her spouse's business and career, told as follows:

"The position of my spouse was going to be closed in the company in Switzerland latest after one year. There, he was required to seek another job by our own means. Actually, I didn't want that. And he didn't want that either. Thus, he was promoted to another position in here." (Betül)

All the women who took part in this study were working on a full or part time basis prior to their immigration to the UK. The majority of them were suffering from mobbing at their workplaces and some of them did not like to work in private sector despite enjoying their positions in Turkey. They all were very satisfied by their career in Turkey.

\section{Challenges as experienced by the participants}

Nearly all the participants had had hard times when they had been to the UK for the first time. Majority of the participants had difficulty in finding the support they required due to having employed spouses, and due to staying at home along with their children. They specified that maybe one of the most difficult parts of living abroad is being distant from their comfort zones in Turkey, and from their families and from the environment which may support them. And many participants specified the problem of language as one of the difficulties faced in the initial days. The immigrants are having much more difficulty in countries where they are unable to speak the language of such country. For instance, Elif expressed the difficulties of both being with a small child, and working abroad for the first time following immigration as follows:

"When I look back, I'm thinking how I did it. You're right. Of course, one is handling everything faced in that period. Actually, that was very hard for me. I was experiencing working abroad for the first time. For instance, the people generally try to go abroad when they are young. I was 34. Okay, it was not too late, but I had difficulty. My spouse was already continuously travelling. And this time, he started to go to other countries. And we again became unable to see each other." (Elif)

Reasons behind mother's preference for staying at home

The participants told that they were very interested in career progression, but that they were obliged to stay at home due to child care. They, however, were concerned about losing their 
skills due to the break they had in their professional lives. For instance, Fatma, who was an interior architect, explained that she definitely wanted to work in the UK and keep up with her career, and added:

"I don't when I'll able to master this foreign language. I need a bit more time. Especially in my profession, it is required to be at a specific level. No matter how old I am. I stuck upon my dreams. That is to say, I want to perform my profession in here too. " (Fatma)

Hatice, who was a teacher, and who had 2 children, said that she felt like having fallen into chaos due to change of country. She expressed that she was having difficulty especially due to lack of a social environment and said the following with regards to working again:

"In here, I tried to apply to a job once, but the hours are very different. I don't know who will take care of the children. Even if I leave one of them to someone, who will take the other from school? That is to say, you have to think of everything. There are no close friends. Due to not having anyone to trust, we finally decided that I should take care of them. " (Hatice)

Some of the participants had worked in various positions in the UK. And often the jobs they had experienced had not complied with their education, and with their previous experiences. But they had still felt good for being able to work in a foreign country. Some participants had had to resign as they did not want to neglect their family due to inflexibility of working conditions. And especially when the children were the case, the women had felt highly desperate. Because, as they did not have anyone to get support except from their spouses, they had been the main careers of their children.

\section{DISCUSSION}

The data suggests that the careers of mothers, who immigrate to the UK along with their spouses, are being interrupted, and that they are being obliged to opt for housewifery and motherhood being the requisite of social gender roles. Mincer [28] explains that while immigration is decreasing the unemployment of men, it is increasing the unemployment of immigrant women accompanying their spouses. Mincer [28] and Sandell [29] have revealed that women are generating less income following immigration. Consequent immigration has interrupted the permanence of labor of women, who had been obliged to immigrate due to their spouses, and thus it has caused the women to work with lower salaries. Accordingly, the women are being obliged tolerate the negative effects of consequent immigration. Krieger [30] indicates by his study that the possibility of employment of men, of any type of immigrants, is significantly higher than that of the women. Moreover, equal employment possibility of male and female leaders and immigrants is higher than that of consequent immigrants.

Brain waste/loss has been used to define the immigrants who work in unqualified worker's jobs despite having the professional qualifications. In a study conducted by Fossland
[31], it has been observed that even if most of the female immigrants had spent time on their careers in early ages, the immigration is causing devastating consequences for their careers due to traditional gender roles. The researches made have indicated that immigration may impair especially the careers of qualified female immigrants [31]. The data of our study is in conformity with these results. The incomes of all the participants had decreased following immigration and their statuses in employment in the UK had been lower compared to Turkey. It is maybe lower than their British/Irish/Welsh/Scottish colleagues having similar qualifications, work experiences, and child care limitations.

The employment/career preference of many participants following immigration is dependent on the careers of their husbands and/or on the welfare of their children. And this generally implies working on a part time basis, or not working at all. Some of them had moved from a country to another along with their husbands for their husbands to maintain their career development. Based on previous studies undertaken with women migrating to different countries along with their spouses [32-35], it has been revealed that most of these women had no realistic alternatives against replacement in the decision-making process. This incapability has been imposed by the ideologies of social gender roles indicating the women as primary care providers, and the men as primary ones earning a living for the family. For this reason, in some circumstances the interests of the family (improving the financial status, supporting the careers of their husbands etc.) are giving the required motivation to women for going abroad [36]. Our data is supporting these results. Most of the participants told us that they had no other choice when their spouses had made the decision for immigration.

Among the immigrant women, it has been observed that their levels of activity and employment are decreasing following parenthood. The immigrant women are having more difficulty in finding jobs compared to the female habitants of the receiving country, and they are being required to consider career positions of lower level [37]. Similar findings were obtained also in this research. Motherhood is negatively affecting the employment of women. The women, who are able to get support for child care and cleaning either from their families or from paid individuals in Turkey, are having difficulty in returning to professional life as they undertake the responsibilities of child care and house chores following immigration.

As a result of the tension between motherhood and professional business roles, the women are desisting from their careers for spending more time with their children. Despite access to education and professional success, the co-existence of family and career roles is being a problem for women. Successful women with higher education are having conflict between their career and family [21]. And similar results were obtained also by this study.

According to studies on immigration of families, conducted in the last 3-4 decades, immigration is positively contributing to 
the career of the male spouse, but it is interrupting the career of the female spouse [38]. Basic empiric generalization regarding that immigration of family is generally providing benefit the male spouse has been verified by many researches. And in this study, it was observed that the spouses of participants were continuing to work as similarly to their previous works, and that some spouses were becoming unemployed following immigration. Of course, it may be considered that this circumstance is also being faced due to the present COVID-19 pandemic.

\section{CONCLUSION}

This study revealed the experiences of 20 highly qualified Turkish immigrant housewife mothers in the UK. While these women, immigrating to the UK by accompanying their spouses, had professional careers prior to migration, since moving to the UK some of them found position at least equal to or lower than the positions of their spouses, and they often get stuck in the lowest part of labor market. A series of intertwined factors (inability to find a job, insufficiency of foreign language, and some personal reasons) contribute to the challenges faced by these women who also have childcare responsibilities.

One of these factors is the high-priced childcare service in the UK when compared to Turkey. The mothers have opted to stay at home as the most proper manner of care for their children in a foreign country. In Turkey, the married women with children, who do not possibly face a regression in their professional careers, are facing a regression in their professional careers following migration to the UK compared to their colleagues.

Another factor pertains to the effect of accompanying their spouses. The continuously repeated moving is creating a cumulative negative effect on the career of women who accompany their spouses when migrating. The study findings suggest that among married couples, the priority is often and disproportionately the career expectations of the husband, and that the migration of family is often being associated with the husbands' career development or progression. This decision is consistent with the Turkish culture where the wives are deemed as the supporters of husbands. It is possible that the women, who accompany their spouses, may not have a career in the UK, and that their possibility of having an advanced professional career is higher in case they stay in Turkey.

This is a negative consequence of moving for the families, and loss of human and social capital. The reason behind this this is the inability to easily transfer such capital forms to countries having significantly different cultural environments.

Another significant factor that contributes to the challenges faced by the participants in this study is social gender roles. Social gender roles seem to be the most effective factor in familial decisions among immigrant Turkish couples. Turkish social gender norms provide more power for the husband in patriarchal family system even it is not required for them to bring in more valuable resources as claimed by the advocates of power of marriage theory [39].

Consequently, the findings of this study suggest that highly qualified Turkish women with children and career who migrate to the UK along with their spouses seem to be unable to succeed in breaking the chains of traditional social gender roles, and that they are not only undertaking childcare responsibilities but also assisting the careers of their spouses for maintaining a harmonious family environment. As a result, they are facing a regression in their own career and socioeconomic statuses.

The UK must make efforts to better understand the problems faced by the highly qualified immigrant women and develop policies for ensuring their participation in labor. Social cohesion is also as important as participation in labor. For this reason, various activities should be organized by local administrations for such women to extend their social networks. More opportunities should be provided for immigrant women regarding language (including business English). This will return as contribution to labor and economy. Following elimination of the language problem of such women, trainings and seminars, by which they may refresh their business-related skills, can be organized, and they can be brought together with employers. In addition, training and education programs can be organized by the government in tandem with the employers. More academic studies on this subject and social policies with respect to immigration for minimizing the problems are required.

\section{REFERENCES}

[1] Hodson Randy, Teresa A. Sullivan (2002) The Social Organization of Work. 5. B., Belmont, CA: Wadsworth,

[2] Castles Stephen, Hein De Haas, Mark J. Miller (2014) The Age of Migration: International Population Movements in the Modern World (5th edn), Basingstoke: Palgrave Macmillan.

[3] Ons, Mike James, (2020) Migration Statistics Quarterly Report. Office for National Statistics, 2020.

[4] DeSimone Susan Donley (2001) Exploring The Effects of Guilt, Spousal Support and Role Conflict on the Psychological WellBeing of the Educated Full-Time Stay at Home Mother. University of San Diego, ton.

[5] Thompson Linda, Alexis J. Walker (1989) Gender in Families: Women and Men in Marriage, Work, and Parenthoo. Journal of Marriage and the Family, 51(4), 845.

[6] Bonıfacıo Glenda Tibe (ed.) (2012) Feminism and Migration: Cross-Cultural Engagements. Canada: Springer,

[7] Avenarius Christine B. (2012) Immigrant Networks in New Urban Spaces: Gender and Social Integration. International Migration, 50(5), 25-55.

[8] Zuo Jiping, Shengming Tang (2016) Breadwinner Status and Gender Ideologies of Men and Women regarding Family Roles. 43(1), 29-43.

[9] Bernard Jessie (1982) The Future of Marriage, New Haven. CT: New Haven and London: Yale University Press, 


\section{Business and Management Research (IJBMR)}

Research Article | Volume 9, Issue 1 | Pages 45-50 | e-ISSN: 2347-4696

[10] Dubors Ellen (1975) The Radicalism of the Woman Suffrage Movement: Notes toward the Reconstruction of NineteenthCentury Feminism. Feminist Studies, 3(1), 63-71.

[11] Hays Sharon (1996) The Cultural Contradictions of Motherhood, New Haven. CT: Yale University Press.

[12] Walsh Froma (2003) Changing Families in a Changing World: Reconstructing Family Normality. Normal Family Processes: Growing Diversity and Complexity (3rd edn), New York: The Guilford Press, pp. 3-26.

[13] Eisenmann Linda (2010) Creating a Framework for Interpreting US Women's Educational History: Lessons from Historical Lexicography.

[14] Marneffe Daphne De (2004) Maternal Desire: On Children, Love, and the Inner Life. New York: Little Brown and Company,

[15] Lerner Harriet (1991) Women in Therapy. Northvale, NJ: Jason Aronson Inc.

[16] Gutek Barbara A, Sabrina Searle, Lilian Klepa (1991) Rational Versus Gender Role Explanations for Work-Family Conflict. Journal of Applied Psychology, 76(4), 560-568.

[17] Elvın-Nowak Ylva (1999) The Meaning of Guilt: A Phenomenological Description of Employed Mothers' Experiences of Guilt. Scandinavian Journal of Psychology, 40(1), 73-83.

[18] Reeder Linda (2001) Conflict Across the Atlantic: Women, Family and Mass Male Migration in Sicily, 1880-1920. International Review of Social History, 46(3), 371-391.

[19] Stone Linda Shapiro (1987) Women Who Have a Graduate School Education Who Have Chosen to Make Mothering The Major Focus of Their Time: A Descriptive Study.

[20] Manetta Brea Ann (1992) Self-Concept as It Relates to Maternal Satisfaction. The Fielding Institute.

[21] Rubin Stacey, Ray Wooten (2007) Highly Educated Stay-atHome Mothers: A Study of Commitment and Conflict. The Family Journal, 15(4), 336-345.

[22] Faludi Susan (2009) Backlash: The Undeclared War Against American Women. New York: Crown,

[23] Majewsk1 Janice Louise (1983) The Impact of Perceived Role Conflict on the Transition to the Maternal Role. San Francisco: University of California,

[24] Seagram Samantha, Judith C Daniluk (2008) It Goes with the Territory: The Meaning and Experience of Maternal Guilt for Mothers of Preadolescent Children.

[25] Mills Belen C., Ann Stevens (1985) Employed And Nonemployed Mothers: Differences In Parental Child Rearing Practices. Early Child Development and Care, 22(2-3), 181-194.

[26] Licht Lisa Margot (1998) Maternal Separation Anxiety: Its Relationship to Attachment and Employment. New York: Yeshiva University.
[27] Zımmerman Toni Schindler (2000) Marital Equality and Satisfaction in Stay at Home Mother and Stay at Home Father Families.

[28] Mincer Jacob (1977) amily Migracion Decisions. NBER Working Paper Series, p. 199

[29] Sandell Steven H (1977) Women and the Economics of Family Migration. The Review of Economics and Statistics, 59(4), 406414

[30] Krieger Magdalena (2019) Tied and Troubled: Revisiting Tied Migration and Subsequent Employment. Journal of Marriage and Family, 1-1

[31] Fossland Trine (2013) Crossing Borders-Getting Work: Skilled Migrants' Gendered Labour Market Participation in Norway. Norsk Geografisk Tidsskrift-Norwegian Journal of Geography, 67, 276-283.

[32] Harvey Michael (1998) Dual-Career Couples During International Relocation: The Trailing Spouse. The International Journal of Human Resource Management, 9(2), 309-331.

[33] Cooke Fang Lee (2007) Husband's Career First: Renegotiating Career and Family Commitment among Migrant Chinese Academic Couples in Britain. Work, Employment and Society, 21(1), 47-65.

[34] Cooke T. J. (2001) Trailing wife' or 'trailing mother'? The effect of parental status on the relationship between family migration and the labor-market participation of married women. Environment and Planning A, 33(3), 419-430.

[35] Manzonı Chiara (2017) Should I stay or should I go? Why Roma migrants leave or remain in nomad camps. Ethnic and Racial Studies, 40(10), 1605-1622.

[36] Erten Elif (2017) Almanya'ya Evlilik Yoluyla Göç Eden Kadınların Karşılaştıkları Güçlükler ve Güçlükleri Yenme Stratejileri. İstanbul Üniversitesi,

[37] Kil Tine vd. (2018) Employment After Parenthood: Women of Migrant Origin and Natives Compared. European Journal of Population, 34(3), 413-440.

[38] Amcoff Jan, Thomas Niedomysl (2015) Is the Tied Returnee Male or Female? The Trailing Spouse Thesis Reconsidered. Population, Space and Place, 21(8), 872-881.

[39] Shihadeh Edward S. (1991) The Prevalence of HusbandCentered Migration: Employment Consequences for Married Mothers. Journal of Marriage and the Family, 53(2), 432-444.

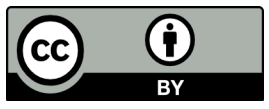

(C) 2020 by the Arzu Kircal Sahin and Dr. Serpil Aytac. Submitted for possible open access publication under the terms and conditions of the Creative Commons Attribution (CC BY) license (http://creativecommons.org/licenses/by/4.0/). 